\title{
Disaster risk reduction and resettlement efforts at San Vicente (Chichontepec) Volcano, El Salvador: toward understanding social and geophysical vulnerability
}

\author{
Luke J Bowman ${ }^{1 *}$ and Kari B Henquinet ${ }^{2}$
}

\begin{abstract}
Despite a long history of volcanic debris flows on the northern flank of San Vicente Volcano, El Salvador, authorities and communities were ill-prepared for the lahars that occurred on Nov. 7-8, 2009. More than 250 people were killed by lahars resulting from shallow landslides, not to mention millions of dollars (US) in damage to houses, agriculture, and infrastructure. After the disaster, significant aid was invested in the region to reduce risk in future disasters. This case study uses the ethnographic tools of qualitative interviews, participant observation, and review of institutional documents to analyze two particular aspects of disaster risk reduction strategies in the town of Verapaz: 1) relocation of at-risk residents led by the Ministry of Housing and Urban Development, and 2) hazard monitoring and emergency management training programs led by Civil Protection, the University of El Salvador, and NGOs. The relocation effort, while effective at reducing physical vulnerability to debris flows, failed to incorporate livelihood, social networks, and cultural ties to homes in their project design and implementation. Since diverse livelihoods are keys to survival, and tightly-knit social networks help families share responsibilities and withstand shocks during hardships, many families returned to the high-risk area or opted not to relocate. Others have adapted using unanticipated strategies to benefit from the resettlement effort. On the other hand, the emergency management training and education programs valued local input, knowledge, and action, which has helped increase awareness and improved the overall capacity to manage emergencies through wide, local participation. The different approaches used in the two risk reduction initiatives reveal important lessons regarding the importance of community participation. Challenges derive from narrow understandings of vulnerability on the part of disaster risk reduction experts, who neglected to consider and understand kin networks and residence patterns that help maintain diverse livelihoods, as well as ensure safety and security. As demonstrated in the 2011 Tropical Depression 12E, effective public engagement and empowerment helped bridge the knowledge, awareness, and preparedness gaps that existed prior to the 2009 disaster.
\end{abstract}

Keywords: Disaster risk reduction; El Salvador; Relocation; Resettlement; Vulnerability; Livelihoods; Volcanic hazard; Early warning system; Debris flow

\section{Introduction}

Strategies for disaster risk reduction (DRR) in the aftermath of hazard events have evolved over the last decade. The "Hyogo Framework for Action 2005 - 2015" sponsored by United Nations International Strategy for Disaster Reduction (UNISDR) emphasized sustainable development

\footnotetext{
*Correspondence: ljbowman@mtu.edu

'Department of Geological and Mining Engineering and Sciences, Michigan Technological University, 1400 Townsend Drive, Houghton 49931MI, USA Full list of author information is available at the end of the article
}

and disaster prevention rather than reactionary responses (i.e., search and rescue and provisional sheltering) to catastrophic events (United Nations 2007). Many countries, including El Salvador, are adapting their risk reduction strategies around a plan of prevention; however, when disasters do occur, especially in developing countries, governmental and non-governmental relief and development institutions continue to consider relocation policies as viable, go-to strategies to remove people from geographically hazardous areas. These strategies narrowly focus on natural 
hazard vulnerability, while giving little thought to other types of vulnerability. The case of the response to the 2009 San Vicente, El Salvador disaster illustrates this point, while also showing ways in which natural hazard monitoring and communication improvements have been made.

In November 2009, heavy rains at San Vicente volcano in Central El Salvador (Figure 1) triggered shallow landslides that formed lahars. The debris flows affected several communities on the northern flank of the volcano, including Verapaz, triggering a massive relief and recovery effort. Nationally, disaster losses totaled approximately $\$ 240$ million (USD), which represents more than 1.1\% of GDP (United Nations 2010). Within the housing sector alone, more than 20,000 homes were either destroyed, badly damaged, or declared to be at-risk (United Nations 2010). Five months after the event, a $\$ 3.8$ million (US) plan to relocate the most at-risk neighborhoods in Verapaz was underway (Ministerio de Relaciones Exteriores de El Salvador 2012). This research examines the ways in which at-risk populations in the small town of Verapaz were involved in mitigation programs and assesses the outcomes of these programs. Results demonstrate that despite best efforts, a significant gap persists between the authorities' perception of program success and the experience of the at-risk population near San Vicente. In particular, we examine this gap in the implementation of the resettlement project, and we contrast this with more successful DRR initiatives that involved local residents in hazard monitoring strategies and communication. The 2009 debris flow disaster resulted in traumatic experiences for rural Salvadorans and underscored the challenges in implementing effective risk reduction when livelihoods and social support networks are disrupted.

Despite these shortcomings, new and sometimes unplanned livelihood and disaster preparedness strategies slowly emerged as families adapted to new settlement patterns after 2009. A long history of repression and the imposition of unfavorable settlement policies have stifled poor Salvadorans' social mobility, but also fostered creative ways in the disaster's aftermath for some to benefit from post-event relocation. Affected residents largely fall into four distinct groups: 1) those who lost everything and relocated to New Verapaz; 2) those who attempted relocating but returned to their original homes; 3 ) those who used the relocation project to claim an additional home to expand livelihood activities, and; 4) those who remain in risky areas of Verapaz and have no intention of relocating to New Verapaz. The relocation effort had mixed results; some thrived while others struggled in the new settlement and opted to return to their old homes.

We first situate this study within the existing literature on relocation programs and place Salvadorans' vulnerability within the context of the country's colonial and political history. We next describe ethnographic methods and

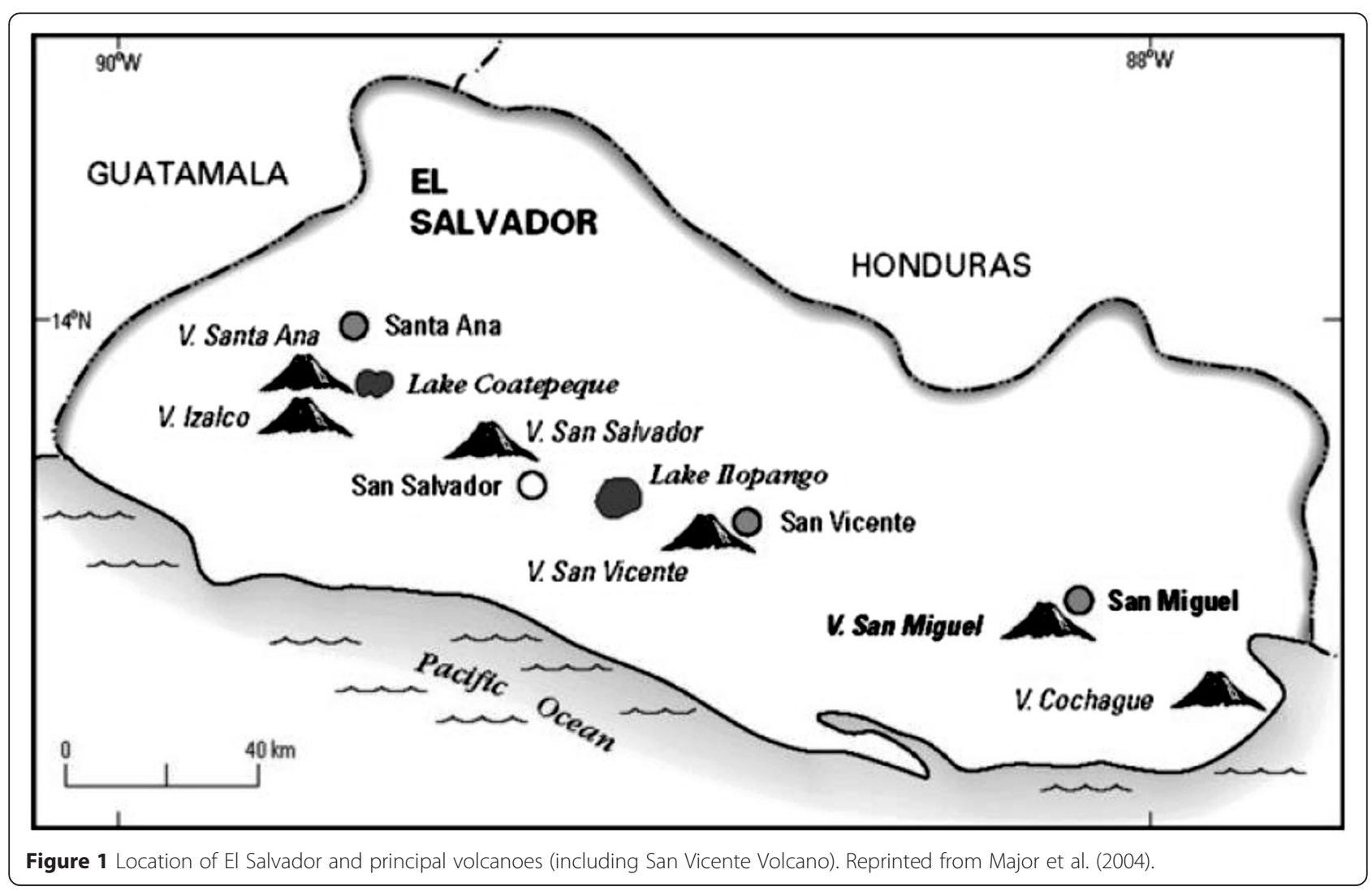


data analysis techniques employed throughout this study. In the results and discussion, we analyze the outcomes of uneven integration of the concerns and values of at-risk populations into the resettlement project planning and disaster risk monitoring efforts. In both cases, DRR experts focus on reducing vulnerability to natural hazards rather than incorporating a broader understanding of risk and vulnerability in people's lives in Verapaz. The natural hazard reduction focus was more effective in programs that incorporated communities in ongoing hazard monitoring and communication than in the case of resettlement. This case study illustrates a resettlement program that failed to view the process holistically and incorporate affected residents' concerns. It also highlights the advantages of engaging stakeholders in the scientific and decision-making/risk communication process. We found that resettlement was a more complex issue to plan for and successfully implement than improving communication and promoting local monitoring of natural hazards.

\section{Background}

\section{Relocation of At-risk Communities and Disasters}

Relocation is a complex issue, often resulting in hardships to those affected and in unanticipated outcomes. There is an extensive body of literature describing the challenges and pitfalls of post-disaster relocation projects (Johnson 2007; Oliver-Smith 2009; Cernea 1999; De Wet 2009). Whiteford and Tobin (2004) provide a comprehensive review of cases showing that, "even though the literature on natural hazards and disasters provides ample evidence to suggest that there are significant political, economic, social and physical consequences to resettlement policies... resettlement remains a 'popular solution to hazard and disaster management' (Chan 1995: 22)" (p. 190). Oliver-Smith (1991) reviews cases in Turkey, Iran, Peru, and Guatemala to pinpoint specific aspects of each effort that contributed to either successful and unsuccessful results-one of the most important being public engagement and beneficiary participation in project design and implementation. Macías and Aguirre's (2006) analysis of relocation efforts at Colima volcano in Mexico points towards similar conclusions. Lack of community participation and a topdown, government-mandated approach led to major social conflict. Reluctance to move was also attributed to small home size, poor ventilation, inadequate construction materials, close proximity to other homes, and a general poor design-all aspects that "violate the customs of the people affected by disasters" (Macías and Aguirre 2006: 52). Usamah and Haynes (2012) similarly conclude that relocation efforts at Mayon volcano in the Philippines did not consider broader livelihood concerns, meaningful beneficiary participation, disruption of social networks, nor culturally appropriate housing design. It therefore did not achieve institutions' nor residents' desired goals.

A well-studied, Latin American case occurred at Tungurahua Volcano near the town of Baños, Ecuador where evacuation and relocation experiences resulted in varying perceptions of success. The volcanic activity and subsequent emergency management crisis made residents, authorities, and aid institutions acutely aware of each entity's opposing attitudes regarding evacuation and relocation (Lane et al. 2004). Relocation was the preferred institutional response and, according to the institutions' own analyses, was successful; however some residents have very different, opposing sentiments (Tobin and Whiteford 2002). It may seem intuitive to suggest that relocation is the most effective strategy to completely reduce a population's susceptibility to volcanic hazards-a disaster can only occur when society and a hazard overlap in space and time. While efficient at reducing physical exposure to most hazards, relocation efforts that fail to consider factors influencing social vulnerability can result in "serious, and often permanent, socioeconomic and cultural suffering and impoverishment" for the resettled population (De Wet 2009: 78). Whiteford and Tobin discuss how in the Tungurahua Volcano case "emergency evacuation and resettlement policies unfairly hurt the most vulnerable populations, the poor and the disenfranchised. Such policies are unhealthy because they make it more difficult for families to recover economic losses [and] separate them from their kin and support networks" (2004: 189).

The challenges of livelihood disruption faced in Baños are similar to those encountered by residents of Verapaz, El Salvador. Verapaz is a town of roughly 4,000 residents at the base of San Vicente volcano in an area of steep drainages prone to debris flows and flooding. In both cases, residents were reluctant to leave their homes. In Verapaz, the reasons for mixed relocation success stem from residents' reluctance to abandon their supportive social networks and livelihoods, among other relevant concerns detailed below. Increased social and livelihood challenges in the resettlement dissuaded residents living in high-risk areas from moving to new, free housing. For many residents who did move, social vulnerability increased as families were cut off from support. As OliverSmith (2009) notes, resettlement initiatives designed to avoid disasters can and often do result in unintended "development disasters."

In contrast to top-down implementation of the resettlement by the El Salvador Ministry of Housing and Urban Development, other DRR efforts led by Civil Protection, the Universidad de El Salvador, and various NGOs included broad public engagement in hazard monitoring and risk communication. Public participation in community-based risk reduction can empower stakeholders by forming 
partnerships with NGOs, universities, and other agencies, which can "improve the community understanding and stimulate the willingness to build the culture for disaster prevention and preparedness (Karnawati et al. 2011: 153). Successful community-based early warning systems (CBEWS) are well-documented: Indonesia (Fathani et al. 2014; Karnawati et al. 2011), Philippines (Allen 2006), Italy (García and Fearnley 2012), and Colombia (Coll 2013). The close collaboration of DRR institutions in San Vicente allowed for strategic, well-funded education and training opportunities for local residents to form a CBEWS. These systems focused on communication during emergencies and empowered local observers to gather information and transfer knowledge around San Vicente volcano. Unlike the relocation cases discussed above, the CBEWS programs do not significantly disrupt people's social and economic lives.

\section{Geophysical Vulnerability in El Salvador}

El Salvador is located in Central America above a subduction zone at the juncture of the Cocos and Caribbean Plates (Figure 1). The tropical climate, along with its geographic location, makes it at risk for a variety of geological and hydrometeorological hazards, including: earthquakes (e.g., 1986, 2001), volcanic eruptions (e.g., 2005, 2013), floods (e.g., 2009, 2011), landslides (e.g., 2005, 2009), debris flows/lahars (e.g., 2005, 2009), tropical storms/hurricanes (e.g., 1998, 2005, 2009), droughts (e.g., 2001, 2012), and tsunamis (e.g., 1902, 1957). El Salvador is frequently ranked in the top ten countries most susceptible to natural hazards by the United Nations and often ranks in the top three (CEPAL 2010). Ninetyfive percent of the Salvadoran population are at-risk of some hazard, according to a 2010 report by the United Nations, and the World Bank ranks the Salvadoran population as the second most exposed to "relatively high mortality risk from multiple hazards" (UNDAC 2010; Government of El Salvador 2009; Dilley 2005; World Bank 2006).

El Salvador's precarious geographic location presents many hazards, but other countries exposed to similar hazards (e.g. Chile, Colombia) do not experience comparable disaster losses (De Greiff and Shashank 2012). Frequent experience with costly disasters has not necessarily translated into improved hazard mitigation in El Salvador, nor have DRR institutions succeeded in adequately preparing populations to face hazards and their consequences (Wisner 2001; Bowman and White 2012).

\section{Social Vulnerability in San Vicente}

El Salvador's colonial and political history shapes the rural poor's extreme situation of social and geophysical vulnerability. El Salvador was a Spanish colony from the early 1500 s to the early 1800 s, and criollo elites ruled large estates, establishing dominance over indigenous populations. El Salvador's economy has been predominantly based on agriculture. The early colonial sistema de encomienda (system of entrustment) was the Spanish crown's method to establish and maintain the Spanish criollo and mestizo elites' dominance in all facets of Salvadoran life and inhibit the indigenous population's upward mobility (Boland 2001: 16). Encomiendas allowed control over large tracts of arable land that left the indigenous populations with one option - forced labor for the elite. The encomienda system "quickly degenerated into slavery" (Boland 2001: 16).

After independence from Spain in 1821, elite landowners occupied the fertile lowlands in order to maximize production of indigo. Processes of elite land tenure further marginalized indigenous populations by pushing them to less-desirable and more hazard prone areas like steep ravines and stream banks (Wisner 2001: 254). In the mid-19th Century, indigo was replaced by artificial dyes and demand for coffee rose (Williams 1994: 71). Finally, in 1881, any communal and State land that remained for use by rural Salvadorans was expropriated to elite families. The national government determined that the communal land system "impedes agricultural development, obstructs circulation of wealth, and weakens family bonds and the independence of the individual;" therefore, peasant farmers were instructed to forfeit their private land titles at which point they could be sold at "public auction to the highest bidder" (Williams 1994: 74). Fertile volcanic slopes were quickly repossessed from indigenous communities for coffee production, which once again dispossessed the Salvadoran poor from their lands. During this period, Haggarty describes that policy-makers:

generally agreed on the promotion of coffee as the predominant cash crop, on the development of infrastructure (railroads and port facilities) primarily in support of the coffee trade, on the elimination of communal landholdings to facilitate further coffee production, on the passage of antivagrancy laws to ensure that displaced campesinos and other rural residents provided sufficient labor for the coffee fincas (plantations), and on the suppression of rural discontent (Haggarty 1988: 1).

The resultant social structure further concentrated wealth and power and ensured that access to education, land ownership, social works, and healthcare were kept out of reach of the oppressed majority (Haggarty 1988: 1). (Wisner 2001: 252-253) describes that "the poor majority have been scratching out a living on tiny plots while selling their labor to the coffee barons" or forced to migrate ever since the 1881 expropriation of land. 
Inaccessibility to land, extreme economic inequality, and a political system favoring the wealthy led to uprisings, rebellions, massacres, and most recently a 12-yearlong civil conflict (1980-1992) which killed 75,000 people (Wisner 2001; Wood 2003: 23, 56). At the start of the war in 1980, "90\% of all farms were less than five hectares, and six families held more property than the 133,000 smallest-scale farmers" (FUSADES and The World Bank 1998: 194). Though some land tenure reforms were established throughout the war to appease combatants, meaningful advancements were not achieved until the 1992 Peace Accords. Even these reforms were plagued by "delays in implementation, disgruntlement concerning the quality of land to be transferred, high land prices, and not surprisingly, political tension" (FUSADES and The World Bank: 197). This political and socioeconomic reality perpetuates Salvadorans' physical and social vulnerability to natural hazards and limits their overall resilience when facing hazard events.

Around San Vicente, the fertile volcanic soil, centralized location, and proximity to the Lempa River make this area an agricultural hub. For these reasons, much of the territory has been managed and/or owned by the wealthy elite since colonization. Presently, the higher elevation is dominated by coffee crops, while the fertile bottomlands are used for sugarcane production. Hence, the poorest residents in Verapaz have settled on the high-risk banks of the Quebradona Creek. Many Vicentinos (people from San Vicente) comment that, "El volcán es de Cristiani"-referring to the fact that nearly the entire volcano is owned by former president Alfredo Felix Cristiani Burkard serving his coffee production enterprise.

\section{Community and Livelihoods in Verapaz}

In order to understand why the communication, education, and monitoring strategies implemented in Verapaz succeeded while the resettlement did not achieve anticipated outcomes of planners, the reader needs some socio-cultural background on the community fabric and livelihood strategies of the residents. The structures of community support and livelihoods that exist in Verapaz are an adaptation to the circumstances of geophysical and social vulnerability described above. These adaptations help explain how these people can live in precarious circumstances.

In 2009 , the ethnically homogeneous, mestizo population of Verapaz municipality was 6,257 , the majority of whom live in and around the town center and government seat in Verapaz (Fundación Intervida 2012). The town is connected to the departmental capital city (San Vicente) by a paved highway on which public transportation runs regularly. There is a municipal government, public health clinic, school center, civil court, National Civilian Police office, and Cultural House that all form the base of institutional support and helped provide services after the 2009 disaster. No formal community organizations are registered with the municipal government in Verapaz; therefore groups that have formed cannot benefit directly from governmental financial support. Similarly, there are no organized governmental or institutional efforts to help diversify livelihoods, strengthen entrepreneurship, or support economic growth or local production of goods. There are four economic-oriented community groups that support sugarcane production, basic grain production, egg production, and women's sewing projects; however no group has an annual budget or outside support (Fundación Intervida 2012).

Livelihoods in the town of Verapaz largely revolve around agricultural activities dominated by a male workforce. Families often rely on women, however, to help diversify livelihoods and income generating activities on top of their unpaid labor in the home. In addition to ensuring a smoothly run family unit, women are largely responsible for small-scale animal husbandry, operating corner stores, producing and selling dairy and sugar-cane-based products, and making and selling corn tortillas. One hundred and fifteen families maintained cows and small-scale dairy production operations, and $85 \%$ of families possessed one to three animals. Household production of chickens, eggs, pigs, and goats is commonplace and culturally valued by the women who manage these activities. Downtown Verapaz is peppered with small mini-mart stores, hardware and agricultural supply businesses, seamstresses, shoe repair shops, and a couple of household-run pupuserias (restaurants) - many of which are overseen by women. Importantly, some families are supported through the more recent influence of remesas-financial support sent from (mostly male) family members that live and work in the United States and other countries. In Verapaz, an estimated $10 \%$ of families receive monies sent from the U.S. to help with daily living expenses, which are often managed by women (Fundación Intervida 2012).

The vast majority of wage earners are employed as daylaborers by larger landowners, and they are considered poor working class (Cabrera and Amaya 2015; Fundación Intervida 2012; San Vicente Productivo 2001). Of the 18 departments in El Salvador, San Vicente Department has the highest concentration of individuals living in extreme poverty (Cabrera and Amaya 2015). In Verapaz, larger land holdings ranged from 11.5 acres (14 hectares) up to hundreds of acres and are concentrated among just 19 households who use them commercially for coffee and sugarcane production or rent plots to local residents (Fundación Intervida 2012). Individual farmers who are not wage laborers rent plots of land from large landowners to plant corn, beans, maize and other vegetables. Many of these small-scale farmers are forced to pursue unfavorable credit options from powerful 
lending institutions or individuals to pay for access to land, seed, fertilizer, and pesticides (Fundación Intervida 2012). Some are also able to claim small plots of land close to steep drainages to cultivate for market and subsistence needs. More than half of the 934 total farmers in Verapaz cultivate less than 1.16 acres (1.4 hectares) of land for their households' use (Fundación Intervida 2012). One resident day-laborer describes typical farm life in Verapaz:

Here we pretty much all do the same... most of us work as campesinos, day-laborers. Maybe a mother had a son in the United States who sent money, but most of us struggle and work in the [coffee] fincas. Or in the cane fields. Cleaning and fertilizing coffee. All of the big fincas are there. He who doesn't like to go to the fincas goes to cut sugar cane or work in the sugar mills. We have to work, even though it doesn't pay well, for food... Here we kill ourselves working. But the profit is for the "Big Guy"-the one who controls the monopoly. - Interview 1 (Male, mid-30s)

This current reality of land availability and ownership are indicative of the historical colonial influence that still plays a major role in livelihood realities for rural farmers. To this day, Salvadorans frequently refer to the influence of "The 14. Families"-an influential group of elite families believed to dominate social structure and politics throughout El Salvador for generations (Haggarty 1988). As of 2009, the poorest $20 \%$ of Salvadorans earned only 3.71\% of total income shared in the country (ranking 116th in income inequality out of 156 countries) (IndexMundi 2014).

The towns of Verapaz, Guadalupe and Tepetitan are currently situated near drainages or directly on top of past debris flow deposits. Citing the inherent danger of living in close proximity to natural drainages, Civil Protection and the National Assembly passed a law in 2003 prohibiting construction and development of land in close proximity (50 meters) to active (or potentially active) drainages (Viceministerio de Vivienda y Desarrollo Urbano de El Salvador 2013). This land is legally "protected" and off limits for ownership and development. However, in San Vicente department this law was not enforced. For poor, landless Salvadorans, squatting in these precarious locations for living and farming practices became their only viable option, which increased exposure to lahar and flood hazards.

This history of unstable land tenure is so deeply entrenched that it continues to be accepted-or at least expected-by Salvadorans. Ties to land and agricultural practices run deep-not because rural farmers pass down large parcels of land from one generation to the next, but because families carry on livelihood practices that have sustained them for centuries. In this largely subsistence and wage-laborer-based agricultural tradition in Verapaz, families, neighbors, and friends are often supportive of one another to help meet basic needs.

Vicentinos have developed diverse livelihood and social networks in the face of systemic marginalization and oppression. These coping strategies benefit tight-knit communities throughout daily life and in times of hardships, war, and disasters. Most importantly, these networks persist today. Residents describe the importance of their family and neighbors during hazard events, and also exhibit their own collective agency to make decisions contrary to institutional plans or directives.

Residents largely describe a supportive, extended familybased structure that provides necessary assistance during times of need and enforces safety and security within the community. Many families are multi-generational and occupy the same residences. These assistance networks were crucial, as survivors reflected on the reliance of family and trusted neighbors that provided rescue, aid, lodging, and basic goods during and after the crisis. The tightly-knit social fabric defining community resilience in Verapaz is fundamental for weathering adversities born by social and economic inequality, as well as those provoked by hydrometeorological events.

\section{Methods}

This study is based on experiences of residents affected by the 2009 lahar disaster but incorporates analysis of institutional interventions realized in the region during the months and years after the event. Understanding social dynamics (historical, organizational, political, and cultural) and clearly identifying which strategies are currently being used by institutions in El Salvador to reduce disaster risk were key components to the study. Field observations, review of literature and primary documents, and in-depth, qualitative interviews of targeted populations regarding the disaster and crisis management experience were collected in San Vicente and Verapaz during a 15-monthlong field season (April 2011 - June 2012) for this ethnographic research project.

A total of 38 in-depth, semi-structured interviews were conducted with four, unique target groups:

- Uninhabitable Zone Residents (12 Interviews) - Most houses in this area were completely destroyed by the lahar, but 13 homes (though heavily damaged) remain standing and are occupied, even though the Ministry of Housing declared this area legally "uninhabitable." One family living in this zone opted not to participate.

- High Risk Road Residents (7 Interviews)

- This is one of several areas located in southern Verapaz deemed "high risk" but is unique as some houses were completely destroyed or heavily damaged in 2009. Though the area was 
heavily affected it was never formally declared "uninhabitable." Eight homes remain and are occupied. One family living in this zone opted not to participate.

- Relocated Residents (8 Interviews)

- These interviews took place in the new settlement, New Verapaz. Four were conducted with residents in permanent homes, and four in temporary homes awaiting permanent homes.

- Disaster Risk Reduction Institution Representatives (11 Interviews)

- These interviews were conducted with representatives from institutions (governmental, non-governmental, academic) working on disaster risk reduction initiatives in the region.

New Verapaz was designed to meet housing needs for 244 affected (or potentially affected) families that lie within the 50 meter boundary of an active (or potentially active) drainage. Most of these families did not experience a direct impact from the 2009 disaster, but the Ministry of Housing and Urban Development sought to avoid future disaster impacts for these at-risk areas. Hence, several other less-affected neighborhoods downstream the Quebradona Creek were deemed "high risk", and these families were offered a new home and encouraged to move. The sample for this study focuses on nearly all of the families within the "uninhabitable" and "high-risk" zones of Verapaz that were devastated in 2009 , as these families would seemingly have the most interest in moving to a new settlement. All of these families have either stayed in their original (often damaged) homes or relocated to New Verapaz but decided to move back to their old "high risk" homes.

The interview guide was developed by both authors and a professor at the Universidad de El Salvador, then further modified as relevant themes emerged throughout interviews. The structure of the interview guide was open-ended so as to minimize researcher bias and to allow for a relaxed conversation that could expand and contract based on the interviewee's comfort with the topic (Morgan et al. 1992; Kempton 1996). The goal of these interviews was to better understand residents' ties to their land, reasons for leaving or not leaving their homes during and after the disaster, reasons for accepting or not accepting homes in the resettlement neighborhood, and experiences (past and current) in working with relief and development institutions that arrived to the region after the 2009 disaster.

All interviews were conducted in Spanish (occasionally alongside a Salvadoran field assistant) and digitally recorded. I (first author) or a Spanish-speaking assistant then transcribed each audio file verbatim. Each transcribed interview was subsequently coded using Atlas.ti software in order to more effectively "search for patterns in data and for ideas that help explain why those patterns are there in the first place" (Bernard 2013 taken from Saldana 2009: 8). A combination of descriptive and values coding was used in order to both "document and categorize" a wide range of varying experiences and opinions from the interviewees but also to "capture and label subjective perspectives" from each participant from the highly variable backgrounds of the aforementioned target groups (Saldana 2009: 6-7). Codes were established for each of the transcribed interviews, based on researcher and informant categories. For example, the broader categories of "Relocation" and "Livelihoods" contain many subcategories and codes (Table 1). And these subcategories were further broken down to identify patterns and differences between informants on these topics.

I (first author) translated each quote used throughout this paper. Field notes taken during each interaction with interviewees were used to complement audio file data. Similarly, I attended a variety of community events, institution-sponsored risk reduction projects, planning meetings, UES-FMP-sponsored DRR courses and workshops, crisis simulations, and an actual emergency (Tropical Depression 12 E, Oct. 2011), which permitted rich opportunities to employ the ethnographic tool of participant observation and acquire key documents on DRR programs. Field notes and key documents were also coded for themes and integrated with the categories determined from the interview data.

Table 1 Example categories, subcategories and codes for data analysis

\begin{tabular}{ll}
\hline Category: Livelihoods & Category: Relocation \\
\hline Subcategory 1: Agriculture & Subcategory 1: Chose to relocate \\
Code: Land owner & Code: Relocation challenges \\
Code: Land renter & Code: Relocation reasoning \\
Code: Day-laborer & Code: Relocation rights \\
Code: Sugar-cane & Code: Relocation benefits \\
Code: Coffee & Code: Relocation and livelihoods \\
Code: Vegetables (Corn, beans, other) & Code: Relocation and kinship \\
Code: Wages, loans, taxes & Networks \\
Code: Affected by 2009 disaster & Subcategory 2: Chose not to \\
Subcategory 2: Small business & relocate \\
Code: Resources available & Code: Challenges to old verapaz \\
Code: Credit/Loans & Code: Reasoning \\
Code: Affected by 2009 disaster & Code: Lahar hazard awareness \\
Code: Impacts post-ida & Code: Legal ramifications \\
Code: Relocated & Code: Livelihoods in old verapaz \\
Code: Not relocated & Code: Kinship networks in old \\
\hline
\end{tabular}


Participant observations were used to triangulate the different data sets.

Interview sampling methods varied between the three target groups. Nearly all of the residents of the uninhabitable zone (12 interviews) and high-risk road (7 interviews) who refused to move to New Verapaz were interviewed. In New Verapaz, the sample was purposive, as it was important to capture perspectives from residents who had moved into their permanent homes (4 interviews) as well as from residents who were still in temporary, prefabricated homes (4 interviews) awaiting completion of their permanent home (Bernard 2013: p. 164 - 167). Key informants (11 interviews) from institutions doing DRR work were chosen based on the first author's interaction and rapport with them over the course of the field work, the informant's expertise and interest in the study, and their involvement with different risk reduction interventions in the region. Participants in this group include faculty from La Universidad de El Salvador Facultad Multidisciplinaria Paracentral, the coordinator and technicians from Civil Protection (municipal, departmental, and regional levels), National Civilian Police, the coordinator and technicians from The Center for Disaster Protection (CEPRODE), and United Nations volunteers.

\section{Results and Discussion}

In response to the 2009 disaster in Verapaz, hazard monitoring strategies improved and a new settlement was built for relocating people living in at-risk zones. The analysis detailed below explains the state of hazard monitoring before and after the 2009 disaster; in brief, communication of hazards improved between DRR experts and local residents, which was demonstrated in a subsequent 2011 emergency. The resettlement project, which aimed to permanently remove residents from at-risk zones and provide them with new homes in New Verapaz, did not meet its goals entirely. Instead the at-risk zones remained fully inhabited, even as New Verapaz filled up with occupants. These unanticipated outcomes reflect the lack of consideration for local livelihoods, social networks, and connections to home when planning the resettlement project. Because the impact of relocation on these aspects of life in Verapaz was not explicitly considered, some families found their social vulnerability was increased in some ways, while others were able to take advantage of new resources to come up with their own hazard mitigation and improved socioeconomic strategies. Both the hazard monitoring and relocation projects focused primarily on geophysical vulnerability - getting people out of the path of the lahars. This understanding of vulnerability lent itself well to increased local participation in monitoring and planning for future lahars or other hazards; however, this was not so straight forward in the case of the resettlement project, which also required serious consideration of factors contributing to social vulnerability.

\section{Disaster knowledge of authorities and at-risk populations: Before and after 2009}

Salvadorans' extreme vulnerability to natural hazards is well-known among practitioners and authorities, but hazard knowledge was not disseminated to at-risk populations or even local authorities tasked with disaster preparedness and response before the 2009 disaster. On the other hand, our data also show that residents did not communicate past experiences with disasters to practitioners and institutions before the 2009 lahar disaster. A complete lack of preparedness, little awareness, and no institutionalized measures for early warning or evacuation contributed to the human and material losses during the disaster. However, improvements in disaster knowledge and communication started to be implemented after the 2009 disaster; the success of these changes was demonstrated by the community response during Tropical Depression 12E in October 2011.

A prime example of hazard knowledge that was never shared with the at-risk population is the case of a comprehensive, country-wide volcanic hazard assessment conducted in 2004. This effort by SNET and the U.S. Geological Survey (USGS) produced a hazard map for San Vicente volcano that defined possible inundations zones and high, medium, and low risk areas for lahars of hypothetical volumes (Major 2004). This work was published (albeit, in English) and made freely available online. For reasons not fully understood, this hazard map was never disseminated to the residents or authorities in any of the five municipalities on the northern flank of San Vicente volcano. There was no enforcement of the 2003 law prohibiting construction within 50 meters of drainages, and no other restrictions were applied in Verapaz concerning where people could build homes, regardless of the fact that past lahars had destroyed parts of the town and that the new map indicated that populated areas were at high risk for debris flows. In fact, according to residents, most were completely unaware that any hazard analysis had ever been conducted in the region.

[The town] disappeared, because they had never done a study. They had never done a study to see if the zone was habitable, but people needed homes, and they risked living so close to a drainage. Practically at the shore of the creek, the neighborhood was constructed. Interview 3

Similarly, the vast majority of respondents allude to their lack of awareness of the lahar hazard in Verapaz, and certainly no one was in any way prepared for the event that unfolded. 
We never took it seriously, that it was possible that there could be such destruction...since no one ever told us that this had happened in the past, we didn't

know. - Interview 2

Though SNET was aware of lahar hazards in the region, information was not disseminated to municipal and departmental government institutions, including Civil Protection, as they were caught completely offguard by the lack of warning and magnitude of the event in 2009.

The event took the government by surprise... afterwards, the government changed [its approach]. Civil Protection representative

It is important to reiterate that the three municipalities near San Vicente considered at high risk for volcanic debris flows (Verapaz, Guadalupe, and Tepetitán) have all experienced these hazards first-hand over the last 100 years. The January and February 2001 earthquakes leveled much of Guadalupe and Verapaz, and in August of the same year a debris flow killed one person and damaged infrastructure. In 1913 and 1934, debris-flow events destroyed a large portion of Tepetitán, for which it is now called Antiguo Tepetitán (Old Tepetitán). This area was abandoned, and survivors resettled at (New) Tepetitán, located a couple hundred meters away from the ruins of Antiguo Tepetitán. Likewise, deposits from this event covered southern Verapaz, destroying homes along the Quebradona Creek and killing many individuals. Memories of this event were, in some cases, orally passed to younger generations. Experience with recurring disasters, however, does not necessarily translate into increased awareness or adoption of preparedness measures.

Grandfather told us when he was just a few months old, the first one occurred...the first one occurred in 1913-in 1913 it happened. Later, the second one occurred around 1934. In '34, this town didn't suffer as much as in 1913. Actually, 1913 was very devastating... practically the same zone that was destroyed in 1913 is where it happened again in 2009. - Interview 3

As the memory of the 1934 disaster faded, Verapaz's expansion slowly encroached to encompass the exact area destroyed in 1934. Some structures, including a new hospital/clinic and many houses, were actually built around large boulders deposited by the 1934 flow because they were too large to move. Entire neighborhoods were constructed on top of lahar deposits, even though elderly residents recall advising builders not to invade the areas closest to the drainage where the disaster occurred in 1934. Some study participants remembered these stories and warnings from the older generation, but only in hindsight after the disaster. Some also expressed their lack of understanding that past events could repeat themselves.

\section{They say-(aside) I don't remember-that in 1934 the volcano washed out, and a large part of Tepetitan was lost with a large part of San Vicente. There was evidence that something had come down [the volcano]. That was in 1934...the people, the new generations-no one believed that another situation would occur. We have personally lived it, and know that it can. - Interview 10}

Notably, representatives from DRR institutions were not aware of residents' past accounts and oral histories. Indeed, most residents acknowledge that past disasters were not openly discussed or considered prior to the 2009 event. This fact represents that there has also been a communication disconnect of local hazard knowledge held by residents that was not openly communicated to scientists and authorities, exposing a two-sided hurdle in risk communication and risk reduction.

\section{The 2009 Event and Official Response}

The 2009 lahar disaster at San Vicente volcano made evident the risk communication and risk reduction problems outlined above. In the end, the disaster spurred the Government of El Salvador (GOES) to expand Civil Protection-led efforts and hire dozens of technicians who were trained and strategically placed in the most atrisk communities. In San Vicente, Civil Protection was free to partner with local GO and NGO institutions to strengthen their own capacity to engage local residents in education, preparedness, and training efforts in order to incorporate them into hazard monitoring activities. The GOS demonstrated its support to the victims through this expansion of Civil Protection. The Ministry of Housing and Urban Development also created a relocation scheme after the 2009 disaster to reduce the risk of people living in government-declared uninhabitable and high risk zones.

Between 11:00 pm - 3:00 am local time (UTC -6 hours) on November 7-8, 2009, a low-pressure system related to Hurricane Ida caused intense rainfall $(355 \mathrm{~mm}$ over a period of five hours) that triggered shallow landslides and deadly debris flows on the northern flank of San Vicente Volcano in Central El Salvador. Lahars inundated neighborhoods of towns in five municipalities (Guadalupe, Verapaz, Tepetitán, San Cayetano Istepeque, and San Vicente) killing more than 250 people and destroying between 130 - 200 homes (Figure 2). Though five 


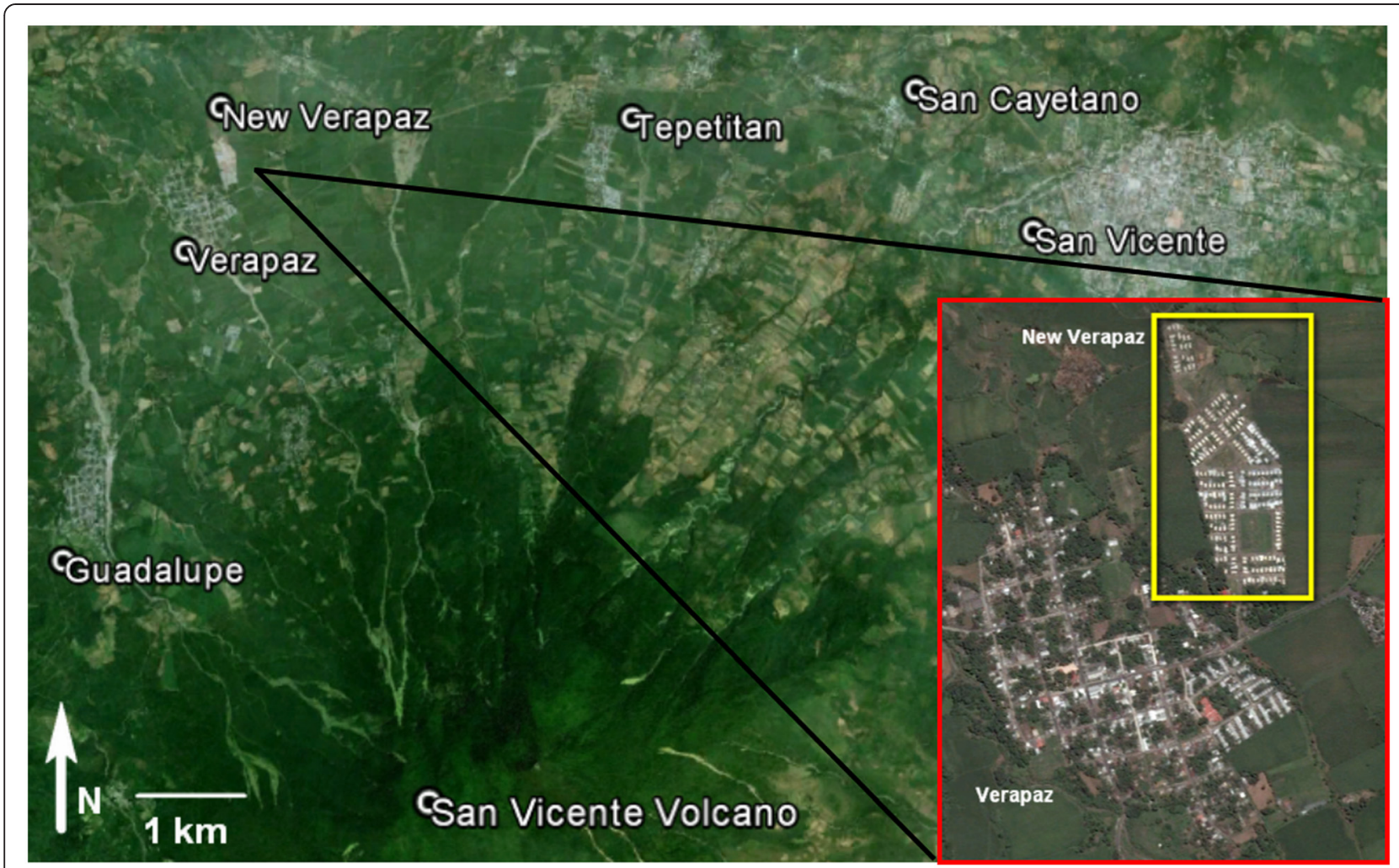

Figure 2 Five affected municipalities encompassing the northern flank of San Vicente Volcano. Inset of Verapaz and New Verapaz, modified from Google Earth (2012).

municipalities encompass the northern flank of the volcano, the town and municipal center of Verapaz immediately became the symbol of the tragedy due to the impressive images of the damage and the tragic stories told by survivors (Figure 3).

Lack of warning and effective preparedness, and the timing and magnitude of the event all exacerbated disaster losses. Rescue and recovery efforts in the immediate aftermath of the disaster provided survivors with shelter, food, clothing, and healthcare. National and international development and aid institutions quickly conducted needs assessments to identify how to best provide for the affected areas and determine longer-term strategies to reduce vulnerability to future disasters (CEPAL 2010; Duran 2010; Government of El Salvador 2009).

Aid poured into the region to help with the short-term recovery effort, and plans for the resettlement in New Verapaz (two kilometers northeast of Verapaz) and additional DRR efforts followed (see inset Figure 2). Survivors reported positive experiences with the generosity offered by volunteers and aid organizations that provided food, clothing, and shelter. In the department of San Vicente, 130 - 200 homes were completely destroyed, so four existing structures (two schools, one church, one community

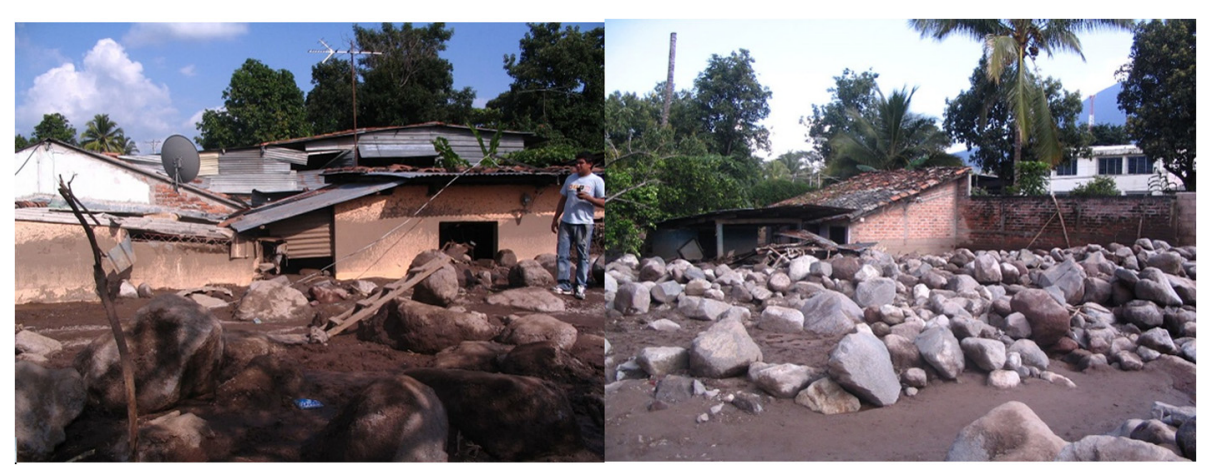

Figure 3 Aftermath of lahar destruction in Verapaz (Photo Credit: Fredy Cruz). 
center) were converted into provisional shelters. Most families reported living in shelters from a few weeks up to three months.

As response and aid distribution shifted from meeting basic needs to a longer-term solution to reduce risk, the Ministry of Housing and Urban Development declared that homes located within 300 meters on either side of the Quebradona drainage were "uninhabitable". This decision immediately made 234 homes off-limits, and most of these families represent the most vulnerable sector of the population that had encroached into dangerous areas (Aguirre 2011). Many families resisted this policy decision-not only the families affected in 2009 but also many who were not directly affected but fell within the 300 meter "uninhabitable" range. To mitigate backlash and provide a more permanent risk reduction agenda, the Ministry of Housing and Urban Development purchased a parcel of land outside the high risk area for the construction of New Verapaz-a proposed settlement of 244 homes for affected residents located two kilometers away from Verapaz (Aguirre 2011; Gobierno de El Salvador 2010). Money for the land purchase and settlement construction was donated from the United Nations Development Program (UNDP), the Panamanian Embassy, Oxfam, UNICEF, the Italian Episcopal Conference, and the municipal government of Verapaz, and costs exceeded 5.4 million (USD). Governmentissued announcements describe the overall goal of the resettlement project to "provide housing and new habitat for families" and meet "minimum basic conditions" for "humble, affected families" but mention nothing regarding community participation, livelihood considerations, or preservation of social networks (Ministerio de Vivienda y Desarrollo Urbano 2013a; Ministerio de Vivienda y Desarrollo Urbano 2013b).

In May 2010 (six months after the disaster), 60 families who had not made their own housing arrangement (temporary or permanent) or had not reoccupied their damaged homes were chosen randomly and given the opportunity to reside in temporary, pre-fabricated homes constructed at the site for New Verapaz (Figure 4). These 60 temporary homes fell far short of the 244 permanent homes the government promised (Aguirre 2011). Slowly, however, the temporary settlement evolved into the permanent solution designed by the Ministry of Housing and Urban Development. Eventually, families that completely lost their homes during the disaster or lived in homes within the confines of the newly designated "uninhabitable" area were offered a new, permanent home in New Verapaz. Groups of homes were constructed in phases, and this process took years. When a house was finished, a lottery was held to determine which family in the list of beneficiaries would receive the house. The vice-minister of Housing and Urban Development, Jose Roberto Gochez, celebrated

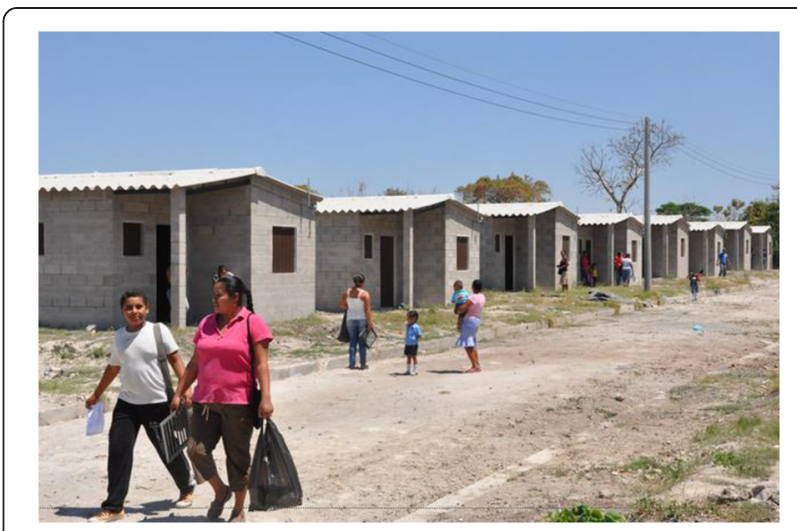

Figure 4 Resettlement homes in New Verapaz (Photo Credit: Ministerio de Vivienda y Desarrollo Urbano 2013a).

commencing the final phase of construction in October 2012 by announcing that "the initiative will benefit 244 families, which in the coming months can count not only on adequate housing but a fully developed habitat" (Ministerio de Relaciones Exteriores de El Salvador 2012). The last batch of 123 permanent houses was not completed until March 2013, more than three years after the event (Ministerio de Vivienda y Desarrollo Urbano 2013a).

Even the President of the Republic, Mauricio Funes, indicated that a change needed to be made in order to avoid future disasters. Five months after the disaster, he addressed the communities of Guadalupe and Verapaz to reassure them that the disaster and the institutional shortcomings will not be repeated in the future.

\section{We promise you, through government support, that new natural disasters will not have the same tragic consequences of [Tropical] Storm Ida. I have assured you personally...next time, institutions will not react the same, and we will not improvise and risk the lives of entire communities by not giving priority to risk prevention...- Mauricio Funes, President of El Salvador (Funes 2010)}

For this reason, the 2009 disaster marks a "before and after" in terms of DRR in El Salvador. It was immediately recognized that the emergency overwhelmed not only the ill-prepared public but also institutional capacity. Lack of awareness, preparedness, and a reliance on reactionary strategies were deemed unacceptable, leading to institutiondriven initiatives to reduce risk in the region. Strengthening Civil Protection's capacity and training, hiring new community-based technicians, and closer collaboration with University of El Salvador investigations and NGO DRR initiatives were all improvements from the previous system. The Center for Disaster Protection (CEPRODE), the National Foundation for Development (FUNDE), the 
Municipalities for the Jiboa Valley (MIJIBOA), Caritas San Vicente Diocese, and a United Nations Development Program (UNDP) project all provided human and financial support to the broadened DRR strategy. An alliance of GO and NGO efforts have been effective at training local residents to monitor rainfall and calculate rainfall rates, better understand precipitation as a landslide/lahar trigger, and use a two-way radio communication network to report daily precipitation data and other observed changes (e.g., surface cracks) directly to the municipal Civil Protection technicians and others in the monitoring network. The results of these institutional efforts have improved hazard awareness and disaster preparedness, as demonstrated below in the response to Tropical Depression 12E in 2011.

\section{Community-based early warning system effectiveness}

The participatory approaches used by Civil Protection, the University of El Salvador, and a cadre of NGOs addressed the knowledge gap through inclusive training and education programs-especially for individuals who opted not to resettle and remained within the uninhabitable zone. These residents are now more vigilant to monitor quickly changing conditions that might indicate a possible lahar. Local monitors go upstream during heavy rains to check river levels and listen for landslides upslope or approaching lahars-information that they spread to the other residents awaiting news in their homes.

\section{We are vigilant about checking on conditions, and we even go up to look at the stream to see how much water there is. - Interview 20 with resident of uninhabitable zone who claimed a house in New Verapaz and goes there during heavy rains.}

\section{In Agua Agria and in San Emigdio my friends pass time on the computer and on Facebook and they tell me when it's raining. For whatever thing is happening, they warn me. - Interview 20 with resident of uninhabitable zone who claimed a house in New Verapaz and goes there during heavy rains.}

Part of this new awareness comes out of having seen first-hand and survived the destruction in 2009. But ongoing institutional efforts have strengthened Verapaz's and the surrounding communities' organizational capacity to monitor environmental conditions. Participant observation carried out by the first author during the training of local observers and during field trips and scientific campaigns showed that community participants are engaged in the scientific process. Observations of local observers' actions and attitudes during the management of a real crisis in 2011 and data gathered from the semi-structured interviews all establish that the partnerships between NGOs, the Universidad de El Salvador, and Civil Protection helped spark and maintain community-level interest in local monitoring initiatives. Rather than be passive recipients of information generated by unknown entities, local observers are actively involved in gathering data and making relevant observations while ensuring that the information is communicated to the authorities and the public.

Local observers within the CBEWS measure rainfall rates and communicate potentially dangerous conditions to local Civil Protection authorities via two-way radios. Observers also use the radios to communicate information to one another and to the municipal hub in Verapaz. Information is then distributed via cell phones, SMS messages, social media, and during emergencies the local Civil Protection technician will communicate information and recommendations via megaphone throughout Verapaz.

Each municipality is equipped with a weather station, a communication hub, and a Civil Protection technician/ liaison; and key actors are trained in standard operating procedures during emergencies. Residents are watchful and learn to recognize potential precursors and signs that might provide warning to future hazard events, such as lahars, landslides, and floods. Residents' decisions to temporarily relocate and evacuate the high risk zone during periods of heavy rain or during official Civil Protection warnings makes effective use of new training, increased awareness, and a safer space provided in New Verapaz. Institutional support has made these improvements a priority, and all of these steps have been realized after the 2009 disaster.

Tropical Depression 12E in October 2011 was the first time the Centers for Emergency Operations (COE) were activated. I (first author) was present during the entire, 12-day-long crisis and used participant observation, field notes, post-emergency reports, and targeted interviews with DRR representatives to analyze the effectiveness of the new emergency management strategy. Though participants' hypothetical roles and responsibilities were taught during a five-month-long emergency management certification course, Tropical Depression 12E occurred before trained individuals could participate in a scheduled emergency simulation exercise. The first real-life application of the training received occurred during the nearly twoweek-long emergency presented by Tropical Depression 12E. The first two days after Civil Protection elevated the hazard alert level and activated the COE, Civil Protection and CEPRODE facilitated the designation of actors' management roles. Also, communication protocols were established between local observers, authorities, and the public. Throughout the following ten days of emergency management, the connection to the network of local observers proved invaluable at reporting data in near real-time, which allowed decision makers to evacuate at-risk residents in a timely manner. As active, trained participants in risk reduction, local residents and DRR 
institutions are better connected and rely on one another to correct some of the past communication and hazard awareness problems. The new COE program was able to successfully utilize the close social networks of the Verapaz Community to communicate critical geophysical data, hazard warnings, and evacuation recommendations.

\section{Mixed Success in Relocation Efforts}

Differing understandings of priorities between outside authorities and Verapaz residents also played out in other medium and long-term assistance provided for disaster mitigation and recovery, particularly the Ministry of Housing and Urban Development's relocation scheme that developed. Relocation planners aimed to permanently remove residents from the uninhabitable and at-risk zones in Verapaz. This was not achieved, although alternate housing was provided and occupied by some extended family members from at-risk households, newcomers to the area, and some at-risk residents downstream whose homes fell within the 50 meter "high-risk" delineation. The results discussed in this section examine, from the viewpoint of families from the at-risk zone, how the resettlement project unfolded, what advantages and disadvantages they saw within the project, and how they came to decide where to reside. Based on their responses, a disruption of livelihoods, social networks, and ties to home were among the most common reasons why residents decided not to permanently relocate from their at-risk homes.

The relocation project design demonstrated a lack of awareness on the part of project planners about day-to-day survival and social vulnerability in Verapaz. Community "participation" in the project was limited to families' obligatory labor during construction of their new homes alongside the contractors hired by the Ministry of Housing and Urban Development. Because of the limited incorporation of local concerns and knowledge, the relocation project brought some unanticipated outcomes. Affected residents largely fall into four distinct groups. Some residents were forced to move to New Verapaz because there were no other viable housing options when their houses were completely destroyed. Other residents initially relocated to New Verapaz but returned to their original, at-risk homes in Verapaz. Another contingent used the relocation project to their advantage by claiming a house in New Verapaz with the intent of remaining in Verapaz while renting the new house for additional income or gifting it to family members in need. Finally, there is a group of residents who remained in Verapaz and has no intention of relocating. The Ministry of Housing and Urban Development struggled to achieve desired objectives, because livelihoods, social networks, and strong ties to homes were not adequately considered during project design and implementation.
Except for homes that were completely destroyed and swept away from their foundations, nearly every other home left standing was cleaned out and reoccupied in the days and weeks after the disaster. Houses that were buried up to their rooftops in mud, boulders, and debris-houses where family members were killed-were patched up, swept out, and made livable. For outsiders (foreigners or national authorities/practitioners), it made little sense that residents would want to reoccupy their former homes after having experienced the trauma of the 2009 debris flows. A seemingly rational institutional response to the situation facilitated the hasty approval of the permanent relocation program by government authorities at the Ministry of Housing and Urban Development. Two actions were taken to facilitate this development project: 1) southern Verapaz was declared uninhabitable, which legally prohibited residents' reoccupation of homes, and 2) the construction of first temporary, then permanent homes in a new settlement-New Verapaz-where affected families could relocate.

Project implementers in the Ministry of Housing and Urban Development deem the initiative a success because each of the new homes is occupied. For the residents in New Verapaz, as described below, physical exposure to the lahar hazard has certainly diminished compared to living in high-risk or uninhabitable zones. However, occupation of these new homes does not mean no one is living in the high-risk or uninhabitable zones. Occupants of the new homes include not only relocated residents from Verapaz, but also outsiders who were able to get included on the beneficiary list, family members who have split off from multi-generational families residing in Verapaz, and residents new to the area renting the new home from families that have moved back to or stayed in Verapaz. In reality, the homes that were not totally destroyed in the uninhabitable zone and high-risk focus area are still nearly completely occupied, as residents are reluctant to relocate mainly due to disruption of livelihoods and unwillingness to abandon social networks. The relocation initiative systematically (yet unintentionally) exacerbates social vulnerability for some households in both Old and New Verapaz, yet also opened some select opportunities for particular families that claimed additional free houses, rented newly claimed homes while continuing to reside in their old homes, or claimed a new home even though they were not affected in 2009.

The 19 families interviewed who have reoccupied their old homes do not live amongst the ruins of their old neighborhood in their original houses because they have no other option. A new home in New Verapaz was made available to each of them. The reasons behind their reluctance to move are rooted in social, cultural, and economic realities that dissuade the population from abandoning a deeply ingrained and advantageous system 
that offers strategies to cope with economic and social vulnerability. Livelihood disruption, deterioration of social networks, and strong ties to original homes are the main reasons why residents were reluctant to relocate.

\section{Disruption of Livelihoods due to Relocation}

Most reluctance to relocate revolves around the different ways this dramatic change would disrupt livelihood strategies. Since most families rely on agriculture, moving away from farmland proved difficult. New Verapaz is too far away from traditional agricultural lands, cherished homes, and other economic opportunities. Access to lands is not only important for convenience, but it is also important to be close to ensure that produce and animals are not stolen.

Our [farm] land is close, but leaving here for [outer reaches of New Verapaz] our lands would be too far away. We barely make enough to feed ourselves.

Having to travel and pay for gasoline would take away any remaining profits. - Interview 1 with resident of uninhabitable zone who chose not to relocate.

One of the advantages [of living here] is this is the zone we work. We work the land. If we leave, we leave everything behind, and it's taken years of effort. Thirty years we've been here, we couldn't leave. We stay here because this is where we have everything, and if we leave, we have to leave it all behind. We would have to start all over, alongside strangers, with a new lifestyle. - Interview 1 with resident of uninhabitable zone who chose not to relocate.

Since homes and some plots are passed from generation to generation, the modifications and improvements are highly valued, especially since the investments required to make these changes take so much work. To abandon years of hard work and dedication to make a place "home" was considered unthinkable.

In addition, homes in New Verapaz are located off the main road and far away from the bus route, so unlike Verapaz very little business traffic arrives to householdrun shops since there is no public transportation into or throughout the new settlement. Relocation meant an inconvenient commute for all residents, including wage laborers and women traveling to participate in market activities. Acquiring reliable transportation from New Verapaz to the main transportation routes in Verapaz proved to be too much for some residents. One relocated individual who decided to return to the uninhabitable zone explained:

Sometimes we got a ride [out of New Verapaz], but sometimes we had to have money to travel, unless we wanted to walk out on foot. Sometimes we found a ride to drop us off [near Verapaz], but afterwards, I said, "Its better if we stay here [at our old house]. Interview 2 with resident who relocated but chose to return to the uninhabitable zone

Increased distance is an inconvenience, but access to electricity and water are vital for many tasks that further diversify income generation. There was no electricity, and there were only communal bathroom facilities in New Verapaz, even two years after the completion of the first round of permanent houses.

Some of us never left [our original home] even from the beginning because there was no electricity [in New Verapaz]. - Interview 2 with resident who relocated but chose to return to the uninhabitable zone. I lived in the new settlement for a year. I lived there for a year because they said they would provide electricity and that we would each have our own bathroom, but that never happened. - Interview 4 with resident who relocated but chose to return to the uninhabitable zone.

For families with diversified livelihoods running small shops that required power (e.g. seamstresses, dairy vendors needing refrigeration, corner store owners), it was impossible to run their business without electricity, which dissuaded small business owners.

There are people here [in their old houses] that have been given new houses there [in New Verapaz] but they don't go because the cheese spoils. There is no way to refrigerate. - Interview 2 with resident who relocated but chose to return to the uninhabitable zone.

Also, gifted plots of land in New Verapaz are small $(10 \mathrm{x}$ 20 meters), especially when compared to the space to which residents were accustomed. Finally, homes are built right next to one another (Figure 4). There is no room in New Verapaz to have animals (e.g., chickens, cows, pigs, goats), which are highly valued in the local culture and help provide families with food and additional income.

\section{Disruption of Social and Kinship Networks and Ties to Home}

In addition to livelihood disruption, the unweaving of the tightly-knit social fabric was a major factor that dissuaded families from relocating. A lottery-type system was employed to help fairly distribute new homes. Similar problems with this style of housing distribution were documented in Turkey, as family units were randomly 
distributed throughout resettlement areas and received homes at different stages of the project (Enginöz 2004). This system, which was specifically engineered to avoid suspicions of political favoritism, had the unintended consequence of destroying familial networks. When families and neighbors were not allowed to move together as one unit into New Verapaz, moving meant that the social capital that this network traditionally provides was fractured. In the nearby Lempa River Basin, social capital was regarded by (Bankoff et al. 2013: 82) as a major factor in "reducing vulnerability and an unavoidable starting point for risk reduction." Residents who had relied on family and neighbors for generations were suddenly forced to live apart in different regions of New Verapaz. New neighbors were sometimes complete strangers, as many of the people on the beneficiary list were homeless individuals who had flocked to the area in hopes of taking advantage of the assistances being offered to the affected population. Families relocated based on the "luck of the draw" lottery system rather than family and kinship units that defined community life in Verapaz.

During times of need, families and proximal neighbors support one another. In many instances, extended families and trusted neighbors occupied an entire block or portion of a neighborhood. Whether it be watching the house while a family member was out of town or working the field, trading different food crops, babysitting or even sharing child-rearing responsibilities, this social support network was key to a smooth-functioning way-of-life. Relying on family and neighbors was considered necessary.

The truth is, with all of the other problems we have, we don't have people here looking for more problems [delinquents] -we don't allow it...life goes on and we live on. At least we survive. The truth is, if you need something but don't have it and I do, then we both get by. It's a form of co-existing. - Interview 3 with resident of high-risk area who never relocated to New Verapaz.

People get along really well here, even more so after [the disaster], we are even more like family. We are more united. It's OK if someone needs something-between everyone we find a way to solve it...I tried to live [in New Verapaz] but it was insufferable. - Interview 9 with resident who relocated but returned to the uninhabitable zone.

Not only did the lottery prohibit extended family and neighbors to move together, the actual size of the new house was not conducive for multi-generational families. The new houses only had two small bedrooms, so the design of the home made it impossible for entire family units to move together. This is one of the primary reasons why newly provided homes in New Verapaz are occupied but existing homes within the uninhabitable and high-risk areas are also occupied by the same extended family. For many families, select members have relocated, leaving the other portion of the family behind because there is simply not enough space.

The mayor came here and told us to go to the new settlement. I told him "Yes" but only if they gave me the same size plot. He said, "No" and that he couldn't give me any more land. The lot is tiny. So I told him, "No thanks." - Interview 1 with resident of uninhabitable zone who chose not to relocate.

In addition to plots and houses being small, houses are very close together, which has caused social problems.

We hear about problems with neighbors, that they don't get along. Remember that when you have houses like that, like in San Salvador, where one wall serves two houses-no way, man! They even know how you sleep, and it's terrible! - Interview 3 with resident of high-risk area who never relocated to New Verapaz.

We are not accustomed to living this way, in these spaces [closely spaced houses]. - Interview 23 with relocated resident whose original house in the highrisk zone was damaged but not destroyed.

This system not only divided familial networks, but it also brought to light a completely different problem-individuals and families from outside Verapaz who mysteriously appeared on the list of beneficiaries to receive houses. Local families continuing to live in their old homes frequently describe "aprovechados"-people from other towns that came to take advantage of the aid by saying they resided in the area but lost everything and are therefore deserving of a new, free house. A majority of interviewees explain that some of the first houses donated were, in fact, given to complete strangers that no one in Verapaz recognized. This resulted in major frustration and overall distrust in the process of project implementation, as well as cultivated suspicions of political favoritism-the very thing the lottery system claimed to avoid.

Some groups of families attempted to circumvent the lottery system by waiting to accept a new, permanent home. They are waiting until the very end of the lottery, even though they might come up "next in line" to receive a new house. This reluctance is based on the hope that if they forego a home when their name is called, at the end of the project, the remaining families will all get to move together in the same area of New Verapaz.

Finally, residents repeatedly refer to their land as their "home" - it is where the family has lived for generations. 
As long as conditions do not improve in New Verapaz, there is no incentive to leave the area that is so familiar and has always proved sufficient to meet basic needs.

I came back in May [2010], and I felt at peace because this is where I have lived for so long... They gave me a provisional house, but I couldn't stand living there. Firstly, because there wasn't power. The house was very small. The sun was so strong, it was so hot in the afternoon-so hot. And the [communal] bathrooms were filthy... - Interview 4 with resident of uninhabitable zone who relocated but returned to original home.

Simply put, New Verapaz is not "home."

\section{Relocation success}

As noted above, a number of unintended outcomes resulted from the relocation scheme. In particular, some of these actually served as DRR strategies, although not in the ways that any DRR experts had intended. For example, the design of the resettlement effort and the distribution of homes at New Verapaz has unintendedly provided an emergency alternative housing option for many of the families that have chosen not to relocate. Having friends, family, or tenants living in their donated house ensures that they have a place to go during emergencies.

Every rainy season we leave. When it gets bad, I leave-I pack my bag and I leave. I am scared, but I live here [uninhabitable zone]. When the rainfall is strong, I go [to the new settlement]. - Interview 15 with resident of high-risk zone who claimed a new house but continues to reside in the original home. People come back here [uninhabitable zone] because they feel more comfortable with everything they have in their homes. But in the rainy season, when the storms come, they leave running. A lot of people still run over there [to the new settlement]. - Interview 19 with resident of high-risk zone who claimed a new house but continues to reside in the original home.

This partial relocation was clearly not the intended result of the new settlement, but at least during times of crisis, families are aware that they are in danger and flee to a safer area.

A successful relocation effort that fully removed people from at-risk zones might be attainable in El Salvador if certain criteria were met, including:

1) A new home with lands equal to or better than previous conditions
2) A guarantee that families, neighbors, and friends live in close proximity to each other, as was the case before the 2009 disaster

3) Access to water, electricity, and sanitation facilities that are essential for healthy living and the needs of small businesses

4) Proximity to farm lands

5) Adequate space and permission to tend chickens, pigs, cattle, goats, etc.

6) Easy access to public transportation

However, these criteria were not met, and as a result, the portions of Verapaz that have been deemed uninhabitable are still occupied.

\section{Conclusion}

The Salvadoran national government and DRR institutions active in the region around Verapaz are making strides to reduce disaster risk within vulnerable Salvadoran communities. Financial, organizational, and human resource support invested in Verapaz and surrounding communities is making a positive contribution in terms of hazard awareness, education, and preparedness. Inter-institutional coordination between Civil Protection, the University of El Salvador, and a host of NGOs improved since 2009, and efforts are now undertaken collaboratively building off the expertise of each agency. The evidence gathered ethnographically in this study shows that institutions and residents are closing the communication gap that existed prior to 2009. These programs and this critical information focus primarily on community-based monitoring, open dialogue and improved communication between residents and authorities, and improved planning to reduce disaster risk.

Nevertheless, a more holistic understanding of vulnerability and risk-including both social and geophysical-was not incorporated by project implementers in Old and New Verapaz, and outcomes were of mixed success. In this case, project design and implementation reduced physical vulnerability for some but could not achieve broader success because livelihoods and social networks were disrupted by relocation. Had the project considered ways to reduce these impacts, residents would likely have been less reluctant to leave their high-risk settlement. In lieu of this, residents adapted the best they could, and some success was achieved by those who took advantage of the program design to help diversify livelihoods while providing alternative housing during emergencies. But many still live in the high-risk and uninhabitable zone with no alternative housing. Others have relocated, but found themselves cut off from vital livelihood resources and opportunities as well as crucial social networks. Providing basic needs, adequate living conditions, and proximity to livelihood activities in addition to allowing family and social networks to relocate together were the 
main factors that residents felt could have aided successful project implementation. Since these criteria were not met, many families that relocated have now returned to their original homes in the higher risk zones, and others never left at all.

Throughout the world, relocation programs will likely continue since they can reduce or eliminate a population's spatial exposure to natural hazards. Success of these programs, as suggested by this study, depend in part on how overall vulnerability (including economic, social, political, etc.) is reduced. Cultural and sociopolitical context varies from country to country and from community to community, making a stepwise, universal relocation "best practices" plan nearly impossible. However, there are some basic tenets that should be considered in order to achieve broader community buy-in. These are:

1) Access to livelihood activities

2) Continuance of social networks

3) Culturally appropriate housing that meets basic needs

4) Community participation throughout the design and implementation of the project

This case study shows how historical land tenure and marginalization of the poor exposed people in Verapaz to the lahar hazard at San Vicente volcano, but that through these struggles important kin and social networks emerged to provide support to one another. While some DRR efforts, like CBEWS may find reasonable success even though they mainly focus on geophysical hazards, this history and these local adaptive strategies to social and geophysical vulnerability cannot be ignored in a relocation scheme. This case also shows the importance of understanding the dynamics and uniqueness of each population before implementing a relocation effort. That said, this approach takes time, money, political will, and institutional capacity, all resources in short supply in the immediate aftermath of a disaster.

\section{Abbreviations}

CBEWS: Community-Based Early Warning System; CEPRODE: Centro de Protección para Desastres (Center for Disaster Protection); DRR: Disaster Risk Reduction; GO: Governmental Organization; NGO: Nongovernmental Organization; GOES: Government of El Salvador; SNET: Servicio Nacional de Estudios Territoriales (National Service for Territorial Studies);

MARN: Ministerio de Medioambiente y Recursos Naturales (Ministry of Environment and Natural Resources); UES-FMP: Universidad de El Salvador Facultad Multidisciplinaria Paracentral (University of El Salvador Multidisciplinary Faculty of the Paracentral); UNDP: United Nations Development Program; UNISDR: United Nations International Strategy for Disaster Reduction; USGS: United States Geological Survey.

\section{Competing interests}

LB partnered with the University of El Salvador during his Peace Corps Response and Fulbright research efforts. His responsibilities as a "Disaster Mitigation Specialist" included fostering coordination and collaboration between various aid institutions and efforts working in the San Vicente region. LB never received any compensation from any organization or entity, as his funding was fully provided through Peace Corps and Fulbright programs. The authors declare that they have no competing interests.

\section{Authors' contributions}

LB conducted all interviews and participant observation, coded qualitative data (interviews, field notes, and documents), translated Spanish quotations into English, and drafted the manuscript. $\mathrm{KH}$ helped with the research design and development of the interview guide, as well as manuscript organization, thesis development, and writing. All authors read and approved the final manuscript.

\section{Authors' information}

LB is a doctoral candidate in the Geology and Mining Engineering and Sciences Department at Michigan Technological University, where professors Bill Rose and John Gierke have promoted interdisciplinary "social geology" research regarding natural hazards in developing countries through the Peace Corps Masters International program. After living two years in rural Honduras as a U.S. Peace Corps Volunteer, six months in El Salvador doing master's research, and ample travel and research throughout Latin America, LB was well-poised to collect ethnographic data in El Salvador. The data collected for this article was obtained during a five-month-long Peace Corps Response project, a nine-month-long Fulbright Student Scholar project, and other intermittent visits. LB lived and worked among the affected communities during the 15-month-long research effort.

$\mathrm{KH}$ is the Director of Michigan Tech's Peace Corps Master's International Programs and a Senior Lecturer in the Social Sciences Department at Michigan Technological University. Trained as a cultural anthropologist, she has conducted ethnographic research in Niger on development institutions, gender, and human rights as well as historical work on Cold War U.S. development and humanitarian aid programs. $\mathrm{KH}$ serves on LB's doctoral advisory committee.

\section{Acknowledgements}

First and foremost, we would like to thank professors John Gierke, Bill Rose, and Sam Sweitz for their support in pursuing this project. We are grateful for financial and project support from the U.S. Fulbright Student program, U.S. Peace Corps Response/El Salvador, NSF/PIRE 0530109, and the NSF

Partnership for Enhanced Engagement in Research (PEER) program for providing the necessary funds to carry out this research. We thank our field assistant, Paty Ramirez, for her help conducting interviews. Thanks to Irene Corrales and Jose Marrero for help transcribing a portion of the interviews. We are grateful to Ing. Fredy Cruz for his support at the Universidad de El Salvador - Facultad Multidisciplinaria Paracentral throughout the Peace Corps Response and Fulbright Students Scholar projects. We would like to thank the residents of Verapaz and New Verapaz for participating in this work and the institutions who all provided logistical assistance and valuable insight: Centro de Protección para Desastres (CEPRODE), Protección Civil, National Civilian Police, and the Alcaldías de San Vicente y Verapaz.

\section{Author details}

${ }^{1}$ Department of Geological and Mining Engineering and Sciences, Michigan Technological University, 1400 Townsend Drive, Houghton 49931MI, USA. ${ }^{2}$ Department of Social Sciences, Michigan Technological University, 1400

Townsend Drive, Houghton 49931MI, USA.

Received: 20 June 2014 Accepted: 27 April 2015

Published online: 09 May 2015

\section{References}

Aguirre L (2011) En deuda las viviendas para damnificados. La Prensa Gráfica. San Salvador. Dutriz Hermanos S.A. de C.V.

Allen KM (2006) Community-based disaster preparedness and climate adaptation: local capacity-building in the Philippines. Disasters 30(1):81-101

Bankoff G, Frerks G, Hilhorst D (2013) Mapping vulnerability: disasters, development, and people. LLC, Earthscan

Bernard HR (2013) Social Research Methods: Qualitative and Quantitative Approaches. SAGE Publications.

Boland R (2001) Culture and Customs of El Salvador. Greenwood Press. 
Bowman L, White P (2012) 'Community' perceptions of a disaster risk reduction intervention at Santa Ana (Ilamatepec) Volcano, El Salvador. Environmental Hazards-Human and Policy Dimensions 11(2):138-154

Cabrera O, Amaya P (2015) Informe Final: Vulnerabilidad Socioeconómico ante el Cambio Climático en El Salvador. Conocimiento y Cambios en Pobreza Rural y Desarrollo. RIMISP. San Salvador, Conocimiento y Cambios.

CEPAL (2010) El Salvador: Impacto Socioeconómico, Ambiental y de Riesgo por la Baja Presión Asociada a la Tormenta Tropical Ida en Noviembre de 2009. CEPAL. Ciudad de México, CEPAL: 21.

Cernea MM (1999) The Economics of Involuntary Resettlement: Questions and Challenges. The World Bank.

Chan WN (1995) Flood disaster management in Malaysia: an evaluation of the effectiveness of government resettlement schemes. Disaster Prevention and Management: An International Journal 4(4):22-29.

Coll MAA (2013) Sistemas de Alerta Temprana (SAT) para la Reducción del Riesgo de Inundaciones Súbitas y Fenómenos Atmosféricos en el Área Metropolitana de Barranquilla. Scientia et Technica 18(2):303-308

De Greiff CC, Shashank M (2012) Review, Redefinition and Development of Disaster Risk Indices to Rank Countries for International Organizations. Master of Science in Civil Engineering for Environmental Risks. Mitigation, Politecnico Di Milano

De Wet C (2009) Does development displace ethics? The challenge of forced resettlement. Development \& dispossession: The crisis of forced displacement and resettlement 77:96

Dilley M (2005) Natural Disaster Hotspots: A Global Risk Analysis International Bank for Reconstruction and Development. Vol. 5. World Bank Publications and Columbia University

Duran E (2010) Síntesis de los informes de evaluación técnica de las lluvias del 7 y 8 de noviembre 2009 en El Salvador: Análisis del impacto físico natural y vulnerabilidad socio ambiental. Ministerio de Medio Ambiente y Recursos. Naturales, San Salvador

Enginöz E (2004) A study in post-disaster home environments: a comparative case study between people living in villages and in the town center of Dinar Turkey. Second International Conference on Post-Disaster Reconstruction in Developing Countries.

Fathani, T., D. Karnawati D, Wilopo W (2014) An Adaptive and Sustained Landslide Monitoring and Early Warning System. Landslide Science for a Safer Geoenvironment. K. Sassa, P. Canuti and Y. Yin, Springer International Publishing: 563-567.

Fundación Intervida (2012) Diagnostico Municipal Participativo de Verapaz 2012. Fundación Intervida, C. E. Ramos. San Salvado, p 88

Funes M (2010) Repoblación parque cafetalero en zonas afectadas por la tormenta IDA, Guadalupe, San Vicente. Discursos, San Salvador

FUSADES and The World Bank (1998) El Salvador. Rural Development Study, The World Bank

García C, Fearnley CJ (2012) Evaluating critical links in early warning systems for natural hazards. Environmental Hazards 11(2):123-137

Gobierno de El Salvador (2010) Ministerio de Gobernación y Desarrollo Territorial. "Gobierno Central entrega viviendas temporales y paquetes domésticos en Verapaz para afectados por tormenta Ida" Accessed 2/5/2015.

Google Earth 7.1.2.2041 (December 13, 2012). San Vicente Volcano, El Salvador. $13^{\circ} 35^{\prime} 49.38^{\prime \prime} \mathrm{N} 88^{\circ} 50^{\prime} 21.78^{\prime \prime} \mathrm{W}$, Eye alt $49161 \mathrm{ft} ., 2014$ CNES/Astrium [6/2/2014].

Government of El Salvador (2009) El Salvador: Damage, Loss, and Needs Assessment for Disaster Recovery and Reconstruction after the low pressure system associated with Tropical Storm Ida. GFDDR, Global Facility for Disaster Reduction and Recovery

Haggarty RA (1988) El Salvador: A Country Study. Library of Congress, Washington, D.C.

IndexMundi (2014) El Salvador - Income Distribution. Country Facts. Retrieved 5/12/2014, 2014, from http://www.indexmundi.com/facts/el-salvador/ income-distribution

Johnson C (2007) Strategic planning for post-disaster temporary housing. Disasters 31(4):435-458

Karnawati D, Fathani TF, Ignatius S, Andayani B, Legono D, Burton PW (2011) Landslide hazard and community-based risk reduction effort in Karanganyar and the surrounding area, central Java, Indonesia. J Mt Sci 8(2):149-153

Kempton W (1996) Environmental Values in American Culture. Woburn, MIT

Lane LR, Tobin GA, Whiteford LM (2004) Volcanic hazard or economic destitution: hard choices in Baños, Ecuador. Global Environmental Change Part B: Environmental Hazards 5(1-2):23-34
Macías JM, Aguirre BE (2006) A critical evaluation of the united nations volcanic emergency management system: Evidence from Latin America. J Int Aff 59(2):43

Major JJ, Schilling SP, Pullinger CR, Escobar DC (2004) Debris-flow hazards at San Salvador, San Vicente, and San Miguel volcanoes, El Salvador. GSA Special Paper. 375.

Ministerio de Relaciones Exteriores de El Salvador (2012) Gobierno inicia la construcción de última etapa de complejo habitacional en Verapaz, San Vicente

Ministerio de Vivienda y Desarrollo Urbano (2013a) Últimas 123 familias reciben casa nueva en Verapaz, San Vicente. Ciudadano, Noticias, Retrieved February 6, 2015.

Ministerio de Vivienda y Desarrollo Urbano (2013b) Viceministerio de Vivienda entrega Parcelación Habitacional para 244 familias de Verapaz. Ciudadano, Noticias, Retrieved February 8, 2015.

Morgan M, Fischhoff B, Bostrom A, Lave L, Atman C (1992) Communicating risk to the public. Environ Sci Technol 26(11):9

Oliver-Smith A (2009) Development and Dispossession: The Crisis of Forced Displacement and Resettlement, School for Advanced Research Press/SAR Press.

Oliver-Smith A (1991) Successes and failures in post-disaster resettlement. Disasters 15(1): 12-23.

Productivo SV (2001) Estudio Agroecológico y Socioeconómico en el Departamento de San Vicente. San Vicente Productivo y Unión. Europea, San Salvador

Saldana J (2009) The Coding Manual for Qualitative Researchers, SAGE Publications.

Tobin GA, Whiteford LM (2002) Community resilience and volcano hazard: The Eruption of Tungurahua and Evacuation of the Faldas in Ecuador. Disasters 26(1):28-48

UNDAC (2010) United Nations Disaster Assessment and Coordination: 2010

United Nations (2007) Hyogo Framework for Action 2005-2015. International Strategy for Disaster Reduction. Extract from the final report of the World Conference on Disaster Reduction, Geneva, Switzerland

United Nations (2010) Surge in Demand for Humanitarian Assistance in High-Risk Environments Informs General Assembly Debate on Strengthening UN Disaster Relief Assistance. $65^{\text {th }}$ General Assembly Plenary.

Usamah M, Haynes K (2012) An examination of the resettlement program at Mayon Volcano: what can we learn for sustainable volcanic risk reduction? Bull Volcanol 74(4):839-859

Viceministerio de Vivienda y Desarrollo Urbano de El Salvador (2003). Marco Normativo para la Ventanilla Única. Government of El Salvador. San Salvador. October 2013.

Whiteford LM, Tobin GA (2004) Saving lives, destroying livelihoods: emergency evacuation and resettlement policies in Ecuador. See Castro \& Singer 2004:189-202

Williams RG (1994) States and Social Evolution: Coffee and the Rise of National Governments in Central America. University of North Carolina Press.

Wisner B (2001) Risk and the Neoliberal State: Why Post-Mitch Lessons Didn't Reduce El Salvador's Earthquake Losses. Disasters 25(3):251-268

Wood EJ (2003) Insurgent Collective Action and Civil War in El Salvador, Cambridge University Press.

World Bank (2006) Natural Disaster Hotspots: Case Studies. Disaster Risk Management Series No. 6

\section{Submit your manuscript to a SpringerOpen ${ }^{\odot}$ journal and benefit from:}

- Convenient online submission

Rigorous peer review

- Immediate publication on acceptance

- Open access: articles freely available online

- High visibility within the field

- Retaining the copyright to your article

Submit your next manuscript at springeropen.com 